\title{
IDENTIFIKASI FAKTOR-FAKTOR YANG MEMPENGARUHI PRESTASI BELAJAR MAHASISWA PROGRAM STUDI PENDIDIKAN MATEMATIKA PADA MATA KULIAH KALKULUS LANJUT TAHUN 2018
}

\author{
Sulasri Suddin*, \\ Fakultas Ilmu Pendidikan Universitas Timor \\ *sulasri.suddin@gmail.com
}

\begin{abstract}
ABSTRAK
Penelitian ini bertujuan untuk mengetahui faktor-faktor yang mempengaruhi prestasi belajar mahasiswa Program Studi Pendidikan Matematika pada mata kuliah Kalkulus Lanjut. Subyek dalam penelitian ini adalah mahasiswa Program Studi Pendidikan Matematika yang memprogramkan mata kuliah Kalkulus Lanjut Tahun Akademik 2018 sejumlah 59 mahasiswa. Data dikumpulkan melalui angket dengan penilaian menggunakan modifikasi skala likert yang terdiri dari 5 pilihan jawaban. Jumlah item pernyataan dalam angket penelitian sebanyak 20 butir. Analisis data dilakukan dengan menggunakan pengujian regresi linier berganda melalui program SPSS for Windows versi 22.0. Berdasarkan hasil penelitian diperoleh bahwa faktor internal lebih dominan berpengaruh signifikan dan positif terhadap prestasi belajar mahasiswa program studi pendidikan matematika dibandingkan faktor eksternal. Lebih lanjut, faktor internal dan faktor eksternal berpengaruh signifikan secara simultan atau bersama-sama terhadap prestasi belajar mahasiswa program studi pendidikan matematika.
\end{abstract}

Kata kunci: Faktor Internal, Faktor Eksternal, Prestasi Belajar

\section{ABSTRACT}

This study aims to determine the factors that influence student achievement in the Mathematics Education Study Program in the Advanced Calculus course. The subjects in this study were Mathematics Education Study Program students who programmed the Advanced Academic Year 2018 course for 59 students. Data was collected through questionnaires with assessment using a modified Likert-type scale consisting of 5 answer choices. The number of statement items in the research questionnaire was 20 items. Data analysis was performed using multiple linear regression models via the SPSS version 22.0 for Windows. Based on the results of the study, it was found that internal factors were more dominant and had a significant and positive effect on students' achievement in mathematics education study programs compared to external factors. Furthermore, internal and external factors have a significant or simultaneous effect on the learning achievement of students of mathematics education study programs.

Keywords: Internal Factors, External Factors, Learning Achievement

\section{Pendahuluan}

Prestasi belajar merupakan hasil evaluasi pendidikan yang dicapai oleh siswa setelah menjalani proses pendidikan formal dalam jangka waktu tertentu dan hasil belajar tersebut berupa angka-angka (Suryabrta, 2006) (hasil yang dicapai dari suatu latihan, pengalaman yang harus didukung oleh kesadaran). Syah (2010), prestasi belajar merupakan hasil yang telah dicapai oleh siswa setelah melakukan serangkaian aktivitas belajar yang berupa perubahan tingkah laku baik berupa kognitif, psikomotorik maupun afektif (tingkat keberhasilan siswa dalam menyampai tujuan yang telah ditetapkan dalam sebuah program). Selanjutnya, Slameto (2003) mendefinisikan prestasi belajar sebagai tinggi rendahnya tingkat penguasaan siswa terhadap suatu materi pembelajaran.

Menurut Syah (2007) faktor-faktor yang mempengaruhi prestasi belajar dapat dikelompokan menjadi tiga macam yaitu: (1) faktor internal (dari dalam diri siswa); (2) faktor eksternal (dari luar diri siswa) yaitu kondisi lingkungan di sekitar siswa; (3) faktor pedekatan belajar yaitu jenis upaya belajar 
siswa yang meliputi strategi dan metode yang digunakan untuk melakukan kegiatan pembelajaran materi pembelajaran. Oleh Ahmadi (2004) menyebutkan faktor internal dan faktor eksternal yang mempengaruhi prestasi belajar. Tergolong dari dalam individu (faktor internal): faktor jasmaniah (fisiologis), faktor psikologis (faktor intelektif: potensial, kecakapan nyata; dan faktor non-intelektif: unsur-unsur kepribadian seperti sikap, kebiasaan, minat, kebutuhan, motivasi, emosi), faktor kematangan fisik maupun psikis, dan faktor lingkungan spritual dan keamanan. Sedangkan yang tergolong dari faktor luar individu (faktor eksternal): faktor sosial (lingkungan keluarga, lingkungan sekolah, lingkungan masyarakat, lingkungan kelompok), faktor budaya (istiadat, ilmu pengetahuan, teknologi dan kesenian), faktor lingkungan fisik (fasilitas rumah, fasilitas belajar, iklim).

Lebih lanjut, Slameto (2010) mengungkapkan faktor-faktor yang mempengaruh prestasi belajar dapat digolongkan menjadi dua yaitu faktor intern yang terdiri faktor jasmani (kesehatan dan cacat tubuh), faktor psikologis (inteligensi, perhatian, minat, bakat, motif, kematangan dan kesiapan), faktor kelelahan (kelesuan, kebosanan) dan faktor ekstern yang terdiri faktor keluarga (cara orang tua mendidik, hubungan dengan orang tua dan angota keluarga, suasana rumah, kondisi ekonomi keluarga, pengertian orang tua, latar belakang kebudayaan), faktor sekolah (metode mengajar, kurikulum, hubungan dengan guru dan siswa lainnya, disiplin sekolah, alat pelajaran, waktu sekolah, keadaan gedung, metode belajar, tugas rumah), dan faktor masyarakat (kegiatan siswa dalam masyarakat, mass media, teman bergaul, dan bentuk kehidupan masyarakat).

Program Studi Pendidikan Matematika sebagai salah satu program studi yang bernaung pada Fakultas Ilmu Pendidikan Universitas Timor diharapkan dapat menciptakan manusia-manusia yang memiliki pola pikir matematika, memiliki perkembangan dan kecerdasan intelektual yang baik, serta mempunyai nilai-nilai disiplin yang tinggi sehingga dapat menunjang dalam mengikuti perkembangan ilmu pengetahuan dan teknologi.

Di program Studi Pendidikan Matematika terdapat banyak mata kuliah yang wajib diprogramkan oleh mahasiswa, salah satunya adalah mata kuliah Kalkulus Lanjut. Sehubungan dengan itu, maka mata kuliah ini memerlukan pemahaman yang baik dari mahasiswa, berdasarkan data yang diperoleh masih banyak mahasiswa yang mengalami kesulitan dalam memahami materi Kalkulus Lanjut. Hal ini ditunjukkan pada tabel berikut ini:

Tabel 1. Data Nilai Mata Kuliah Kalkulus Lanjut Tahun Akademik 2015/2016 sampai dengan 2017/2018

\begin{tabular}{|c|c|c|c|c|c|c|}
\hline Tahun & Jumlah Mahasiswa yang & \multicolumn{5}{|c|}{ Nilai } \\
\cline { 3 - 7 } Akademik & Memprogramkan & $\mathrm{A}$ & $\mathrm{B}$ & $\mathrm{C}$ & $\mathrm{D}$ & $\mathrm{E}$ \\
\hline $2015 / 2016$ & 89 & 3 & 40 & 46 & 0 & 0 \\
$2016 / 2017$ & 68 & 15 & 18 & 10 & 11 & 14 \\
$2017 / 2018$ & 124 & 4 & 15 & 88 & 16 & 1 \\
\hline
\end{tabular}

Jika dilihat dari persentase nilai Kalkulus Lanjut mahasiswa yang mendapat nilai D dan E sejak tahun akademik 2016/2017 terlihat besarnya jumlah mahasiswa yang tidak meluluskan mata kuliah Kalkulus Lanjut. Jika pada tahun akademik 2015/2016 sebesar 0\% pada tahun akademik 2016/2017 meningkat menjadi $36,76 \%$. Walaupun persentase mahasiswa yang tidak lulus $0 \%$ pada tahun akademik 2015/2016, tetapi pada tahun akademik 2016/2017 persentase jumlah mahasiswa yang tidak melulusi mata kuliah Kalkulus Lanjut meningkat menjadi 36,76\%. Sedangkan pada Tahun 2017/2018 persentase mahasiswa yang tidak meluluskan mata kuliah kalkulus lanjut sebesar 13,70\%. Dari data tersebut, terlihat kecenderungan kenaikan jumlah mahasiswa yang tidak berhasil dalam kegiatan belajarnya yaitu banyaknya mahasiswa yang tidak melulusi mata Kalkulus Lanjut setiap tahun akademik. Jika dipandang bahwa kelulusan mahasiswa pada suatu mata kuliah merupakan wujud nyata keberhasilan belajar mahasiswa maka mahasiswa yang tidak lulus mencerminkan kegagalan mahasiswa tersebut dalam belajar. Artinya, mahasiswa yang gagal tersebut mengalami kesulitan belajar khususnya mata kuliah Kalkulus Lanjut.

Jika dilihat dari kualifikasi dosen, pengalaman mengajar dosen dan frekuensi perkuliahan yang dilaksanakan dosen untuk mata kuliah ini seharusnya pelaksanaan perkuliahan mata kuliah Kalkulus Lanjut akan dapat berjalan dengan baik. Namun karena adanya hasil belajar mahasiswa dengan frekuensi tidak lulus cukup besar maka perlu ditelusuri faktor-faktor yang mempengaruhi keberhasilan belajar 
mahasiswa pada mata kuliah Kalkulus Lanjut. Ketidakberhasilan belajar mahasiswa untuk mata kuliah Kalkulus Lanjut dipengaruhi oleh banyak faktor, baik faktor internal (yang berasal dari dalam diri mahasiswa) maupun faktor eksternal (yang berasal dari luar diri mahasiswa).

Untuk mengetahui faktor-faktor yang mempengaruhi keberhasilan belajar mahasiswa pada mata kuliah Kalkulus Lanjut tersebut, perlu dilakukan suatu penelitian. Dalam hal ini telah dilakukan suatu penelitian yang diberi judul: "Identifikasi Faktor-Faktor yang Mempengaruhi Prestasi Belajar Mahasiswa Program Studi Pendidikan Matematika pada Mata Kuliah Kalkulus Lanjut Tahun 2018”. Penulis membatasi masalah yang akan diteliti yaitu faktor yang berasal dari dalam diri mahasiswa (faktor internal) yang dibatasi adalah berupa faktor fisik yaitu sakit, kurang sehat dan cacat tubuh dan faktor rohani yaitu bakat, minat, motivasi dan perhatian. Sedangkan faktor yang berasal dari luar diri mahasiswa (faktor eksternal) yang dibatasi berupa faktor lingkungan perkuliahan yaitu dosen, fasilitas belajar, waktu kuliah dan disiplin dan faktor lingkungan sosial.

Agar tidak terjadi kekeliruan dalam menafsirkan variabel penelitian, maka didefinisikan secara operasional sebagai berikut:

1) Faktor yang bersifat fisik adalah kondisi fisik mahasiswa selama mengikuti proses perkuliahan Kalkulus Lanjut.

2) Faktor yang bersifat rohani adalah kondisi rohani mahasiswa meliputi: bakat, minat, motivasi, perhatian selama proses perkuliahan Kalkulus Lanjut.

3) Faktor keluarga adalah situasi dan kondisi kehidupan keluarga mahasiswa yang mempengaruhi proses belajar Kalkulus Lanjut.

4) Faktor lingkungan perkuliahan adalah situasi dan kondisi lingkungan tempat mahasiswa belajar Kalkulus Lanjut meliputi dosen, fasilitas belajar, waktu kuliah dan disiplin.

5) Faktor lingkungan sosial adalah kemampuan mahasiswa bersosialisasi dengan orang lain atau lingkungan tempat tinggal.

Berdasarkan paparan permasalahan di atas, maka diajukan hipotesis dalam penelitian ini dirumuskan sebagai berikut:

1. Terdapat pengaruh signfikan dan positif secara parsial faktor-faktor (baik internal maupun eksternal) terhadap prestasi belajar Mahasiswa program Studi Pendidikan Matematika pada mata kuliah kalkulus lanjut.

2. Terdapat pengaruh signfikan dan positif secara simultan (bersama-sama) antara faktor internal dan faktor eksternal terhadap prestasi belajar Mahasiswa program Studi Pendidikan Matematika pada mata kuliah kalkulus lanjut.

\section{Metode Penelitian}

Waktu dan Tempat Penelitian

Penelitian ini dilaksanakan pada mahasiswa Program Studi Pendidikan Matematika Fakultas Ilmu Pendidikan Universitas Timor yang memprogramkan mata kuliah Kalkulus Lanjut pada semester genap tahun akademik 2018.

Subjek Penelitian

Subjek dalam penelitian ini adalah keseluruhan mahasiswa yang memprogramkan mata kuliah Kalkulus Lanjut pada semester genap tahun akademik 2018 pada Program Studi Pendidikan Matematika Fakultas Ilmu Pendidikan Universitas Timor yaitu berjumlah 59 orang mahasiswa.

Intrumen dan Teknik Pengumpulan Data

a. Instrumen untuk mengukur faktor-faktor yang mempengaruhi prestasi belajar mahasiswa

Untuk memperoleh data tentang faktor-faktor yang mempengaruhi prestasi belajar mahasiswa, peneliti membuat angket dengan tetap berpedoman pada instrumen faktor-faktor yang mempengaruhi hasil belajar. Jumlah pertanyaan sebanyak 20 butir, yang dikelompokkan ke dalam 2 faktor, yakni 
faktor internal dan faktr eksternal. Angket faktor-faktor yang mempengaruhi prestasi belajar ini beruapa penyataan, jawaban setiap pernyataan menggunakan Skala Likert (Skala 1-5).

Sebelum digunakan dalam penelitian, instrumen faktor-faktor yang mempengaruhi hasil belaar diujicobakan terlebih dahulu untuk melihat validitas dan reliabilitas. Uji coba analisa butir pernyataan menggunaan formula Cronbach's Alpha yang dihitung dengan bantuan computer program SPSS 20.0 for windows.

b. Instrumen untuk mengukur hasil belajar

Instrumen untuk mengukur hasil belajar merupakan instrumen untuk mengukur variabel dependen sebagai akibat langsung perlakuan. Instrumen hasil belajar berupa nilai ujian akhir semester berupa angka, sebelum dikonversikan ke dalam huruf.

Teknik Analisis Data

Data penelitian yang terkumpul berupa nilai faktor-faktor yang mempengaruhi hasil belajar dengan skala likert (1-5) dan hasil ujian akhir semester dengan rentang nilai 0-100. Setelah data berupa nilai faktor-faktor yang mempengaruhi hasil belajar mahasiswa yaitu faktor internal dan eksternal serta hasil belajar telah terkumpul, data dari hasil penelitian dianalisis secara deskriptif, yaitu data disajikan dalam bentuk tabel.

Lebih lanjut, penulis juga menggunakan analisa data statistik dengan perincian sebagai berikut:

a. Untuk menguji rumusan masalah: ada pengaruh faktor internal atau faktor eksternal terhadap prestasi belajar mahasiswa, penulis menggunakan rumus regresi linear.

b. Untuk menguji rumusan masalah: faktor yang paling dominan antara faktor internal dan faktor eksternal yang mempengarhi prestasi belajar mahasiswa juga menggunakan rumus uji-t.

c. Pengujian hipotesis dilakukan pada taraf signifikansi $5 \%$ atau $\alpha=0.05$. Semua analisis statistik menggunakan perangkat lunak komputer SPSS 20.0 for Windows. Hasil pengolahan data tersebut digunakan sebagai dasar untuk melakukan interpretasi hasil penelitian. Sehingga secara jelas dan terperinci faktor apa yang dominan.

\section{Hasil Penelitian dan Pembahasan}

Pada bagian ini disajikan hasil analsis deskriptif identifikasi faktor-faktor yang berpengaruh terhadap prestasi belajar mahasiswa secara umum dengan menggunakan SPSS 20.0

Tabel 2. Analisis Deskriptif

Descriptive Statistics

\begin{tabular}{|l|r|l|r|}
\hline & \multicolumn{1}{|c|}{$\mathrm{N}$} & Mean & Std. Deviation \\
\hline faktor_internal & 59 & 26.1186 & 4.02186 \\
faktor_eksternal & 59 & 41.5763 & 6.09467 \\
prestasi_belajar & 59 & 62.2712 & 11.15847 \\
\hline
\end{tabular}

Sumber: Data Primer Diolah Dengan SPSS 20.0

Berdasarkan hasil analisis deskriptif identifikasi faktor-faktor yang berpengaruh terhadap prestasi belajar mahasiswa diperoleh rata-rata skor faktor internal dan faktor eksternal berturut-turut adalah 26,12 dan 41,58 (pembulatan sampai dua angka di belakang koma) dengan standar deviasi berturut-turut sebesar 4,02 dan 6,09 (pembulatan sampai dua angka di belakang koma). Sedangkan ratarata nilai dan standar deviasi prestasi belajar mahasiswa diperoleh berturut-turut adalah 62,27 dan 11,16 (pembulatan sampai dua angka di belakang koma). Dari segi standar deviasi (simpangan baku), faktor eksternal mempunyai nilai standar deviasi yang lebih besar daripada faktor internal. Hal ini menunjukkan bahwa data skor faktor eksternal lebih beragam atau data faktor eksternal mahasiswa menyebar jauh dari nilai rata-rata.

Berdasarkan perhitungan yang telah dilakukan diperoleh bahwa instrumen faktor internal, faktor eksternal dan prestasi belajar cukup dapat dipercaya sehingga pengolahan data dapat dilanjutkan dengan analisis regresi linier berganda. 


\section{Uji Asumsi Klasik}

\section{Uji Normalitas}

Uji normalitas merupakan bagian dari uji asumsi klasik analisis regresi yang dapat dideteksi dengan melihat Output kurva normal P-Plot of Regression Standardiazed Residual atau titik-titik ploting yang terdapat dalam hasil output SPSS.

Gambar 1. Normal P-Plot of Regression Standardiazed Residual

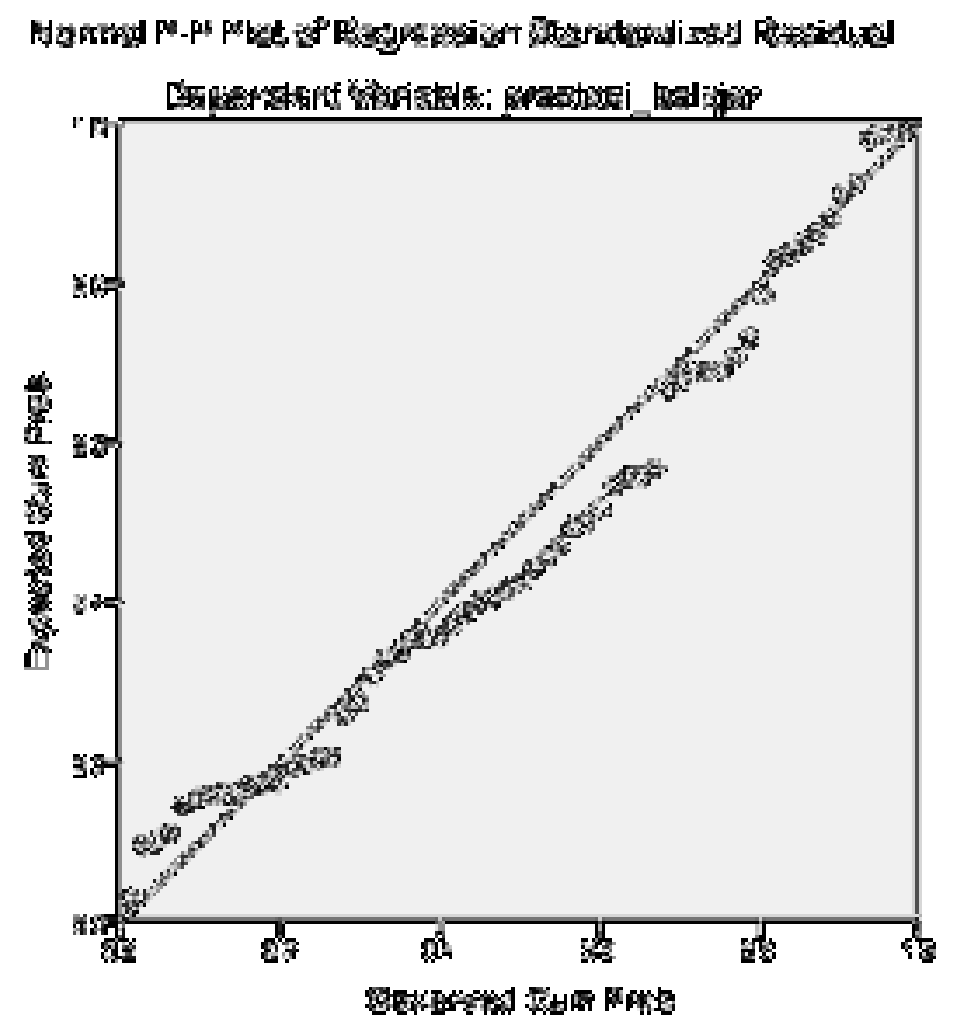

Sumber: Data Primer Diolah Dengan SPSS 20.0

Gambar 1. menunjukkan bahwa titik-titik berada di dekat dan menyebar mengikuti garis diagonalnya. Hal ini membuktikan bahwa nilai residual dalam model regresi ini berdistribusi normal.

\section{Uji Multikolinearitas}

Prasyarat lain yang harus terpenuhi dalam model regresi adalah tidak adanya multikolinearitas/hubungan linear antar variabel independen (faktor internal dan faktor eksternal) dalam model regresi.

Tabel 3. Output Uji Multikolinearitas

\section{Coefficients $^{\mathrm{a}}$}

\begin{tabular}{|c|c|c|c|c|c|c|c|}
\hline \multirow[t]{2}{*}{ Model } & \multicolumn{2}{|c|}{$\begin{array}{c}\text { Unstandardized } \\
\text { Coefficients }\end{array}$} & \multirow{2}{*}{$\begin{array}{c}\begin{array}{c}\text { Standardized } \\
\text { Coefficients }\end{array} \\
\text { Beta }\end{array}$} & \multirow[t]{2}{*}{$\mathrm{t}$} & \multirow[t]{2}{*}{ Sig. } & \multicolumn{2}{|c|}{$\begin{array}{c}\text { Collinearity } \\
\text { Statistics }\end{array}$} \\
\hline & B & $\begin{array}{l}\text { Std. } \\
\text { Error }\end{array}$ & & & & Tolerance & VIF \\
\hline (Constant) & 29.875 & 12.222 & & 2.444 & .018 & & \\
\hline faktor_internal & .987 & .345 & .356 & 2.857 & .006 & .989 & 1.011 \\
\hline $\begin{array}{l}\text { faktor_ekstern } \\
\text { al }\end{array}$ & .161 & .221 & .090 & .727 & .471 & .989 & 1.011 \\
\hline
\end{tabular}

a. Dependent Variable: prestasi_belajar

Sumber: Data Primer Diolah Dengan SPSS 20.0 
Berdasarkan tabel output 'Coeficients' pada bagian Collinearity Statistics diketahui nilai Tolerance untuk variabel independen (faktor internal dan faktor eksternal) adalah 0.989 lebih besar dari 0.10. Sementara, nilai Inflaction Factor (VIF) sebesar 1.011 kurang dari 10.00. Berdasarkan pengambilan keputusan dalam uji multikolinearitas, hasil ini menunjukkan bahwa tidak terjadi gejalan multikolinearitas dalam model regresi.

\section{Uji Heteroskedastisitas}

Uji heterokedastisitas dilakukan dengan tujuan untuk mengetahi adanya penyimpangan dari syaratsyarat asumsi klasik pada regresi linear dan mendeteksi variasi residual pada semua data. Uji heteroskedastisitas yang digunakan dalam penelitian ini adalah dengan melihat pola titik-titik pada output scatterplot.

Gambar 2. Output Scatterplot Uji Heteroskedastisitas

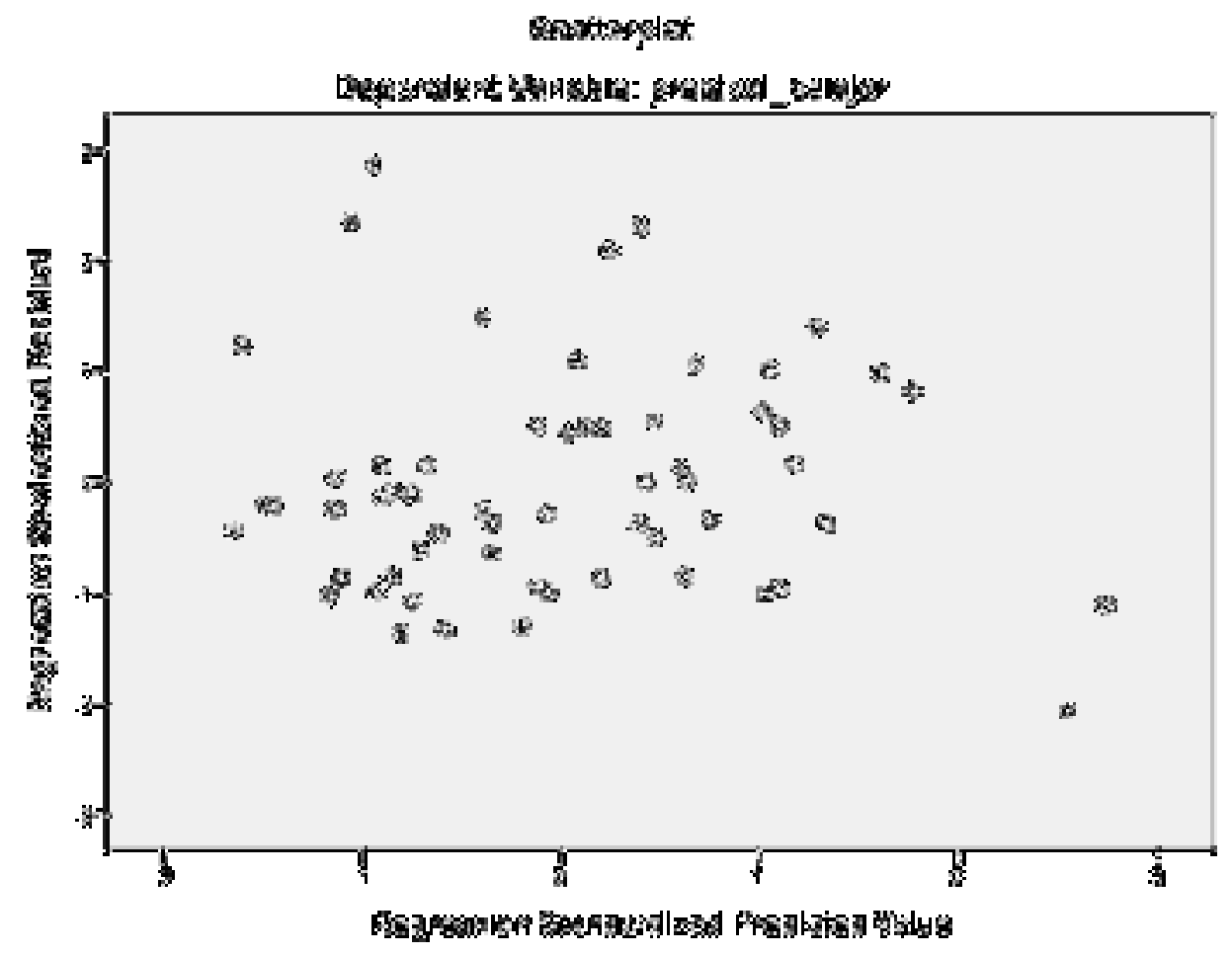

Sumber: DataPrimer Diolah dengan SPSS 20.0

Berdasarkan hasil ouput SPSS yang tertera pada Gambar 2. memperlihatkan bahwa titik-titik menyebar secara acak baik diatas maupun di bawah angka 0 pada sumbu Y. Hal ini menunjukkan bahwa tidak terjadi heteroskedastisitas pada model regresi, sehingga model regresi layak (valid) dipakai dalam penelitian ini.

\section{Analisis Hasil Uji Regresi Linier Berganda}

Persamaan regresi linier berganda pada penelitian ini sebagai berikut.

$Y=29.875+0.987$ faktor internal +0.161 faktor eksternal $+\varepsilon$

Berdasarkan Tabel 3., koefisien regresi untuk faktor internal adalah 0.987, sedangkan nilai koefisien regresi untuk faktor eksternal adalah 0,161. hal ini menunjukkan bahwa faktor yang lebih dominan dalam mempengaruhi prestasi belajar mahasiswa adalah faktor internal. Lebih lanjut, koefisien regresi dari variabel faktor internal sebesar 0.987 menyatakan bahwa setiap penambahan variabel faktor internal sebesar 1 maka hal ini akan menambah besarnya Y (varibael prestasi belajar mahasiswa) sebesar 0,987.

Berikut diberikan Tabel 4. Output SPSS Model Summary yang memberikan informasi mengenai nilai koefisien determinasi, yakni besarnya kontribusi atau pengaruh variable faktor internal dan faktor eksternal secara simultan (bersama-sama) terhadap variabel Y (prestasi belajar). 
Tabel 4. Output SPSS Model Summary

Model Summary ${ }^{b}$

\begin{tabular}{|l|r|r|r|r|r|}
\hline Model & R & R Square & $\begin{array}{c}\text { Adjusted R } \\
\text { Square }\end{array}$ & $\begin{array}{c}\text { Std. Error of } \\
\text { the Estimate }\end{array}$ & $\begin{array}{c}\text { Durbin- } \\
\text { Watson }\end{array}$ \\
\hline 1 & $.376^{\mathrm{a}}$ & .141 & .111 & 10.52296 & 1.149 \\
\hline
\end{tabular}

a. Predictors: (Constant), faktor_eksternal, faktor_internal

b. Dependent Variable: prestasi_belajar

Sumber: Data Primer Diolah dengan SPSS 20.0

Berdasarkan hasil output SPSS pada tabel 4., diperoleh nilai Adjusted R Square sebesar 0.111 artinya sebesar $11.11 \%$ dari prestasi belajar mahasiswa dipengaruhi oleh variabel faktor-faktor internal dan faktor-faktor eksternal, sedangkan siswanya sebesar $88.89 \%$ dipengaruhi oleh faktor-faktor lain yang tidak diteliti dalam penelitian ini.

1. Uji Hipotesis Pengaruh faktor internal dan faktor eksternal terhadap prestasi belajar mahasiswa secara parsial

Untuk melihat apakah ada pengaruh antara faktor internal terhadap prestasi belajar secara parsial dapat dilihat juga pada output SPSS tabel 3. 'Coefficients'. Dari hasil output pada tabel 3., nilai probabilitas untuk faktor internal menunjukkan hasil sebesar 0,006 lebih kecil dari 0,05 $(0,006<$ 0,05) yang berarti Ho ditolak atau dengan kata lain dapat disimpulkan bahwa terdapat pengaruh faktor internal terhadap hasil belajar mahasiswa. Sedangkan nilai probabilitas untuk faktor eksternal menunjukkan hasil sebesar 0,471 lebih besar dari $0,05(0,471>0,05)$ yang berarti Ho diterima atau dengan kata lain dapat disimpulkan bahwa tidak terdapat pengaruh faktor eksternal terhadap hasil belajar mahasiswa.

2. Uji Hipotesis faktor internal dan faktor eksternal Terhadap prestasi belajar mahasiswa secara simultan

Untuk mengetahui apakah ada pengaruh antara faktor internal dan eksternal terhadap hasil belajar secara simultan (bersama-sama) dapat dilihat pada Tabel 5. 'ANOVA' berikut ini.

Tabel 5. Output SPSS ANOVA

ANOVA ${ }^{\mathrm{a}}$

\begin{tabular}{|rl|r|r|r|r|l|}
\hline \multicolumn{1}{|l|}{ Model } & \multicolumn{1}{c|}{$\begin{array}{c}\text { Sum of } \\
\text { Squares }\end{array}$} & Df & Mean Square & F & Sig. \\
\hline \multirow{2}{*}{1} & Regression & 1020.631 & 2 & 510.315 & 4.609 & $.014^{\mathrm{b}}$ \\
& Residual & 6201.030 & 56 & 110.733 & & \\
& Total & 7221.661 & 58 & & & \\
\hline
\end{tabular}

a. Dependent Variable: prestasi_belajar

b. Predictors: (Constant), faktor_eksternal, faktor_internal

Sumber: Data Primer Diolah dengan SPSS 20.0

Dari hasil output pada Tabel 5., nilai probabilitas menunjukkan hasil sebesar 0.014 lebih kecil dari $0.05(0.014<0.05)$ maka Ho ditolak atau dapat disimpulkan bahwa ada pengaruh signifikan antara faktor internal dan faktor eksternal secara simultan atau bersama-sama terhadap prestasi belajar mahasiswa.

Hasil penelitian menunjukkan bahwa secara signifikan faktor internal berpengaruh positif terhadap prestasi belajar mahasiswa program studi pendidikan matematika dengan diterimanya Ho. Atau dengan kata lain terdapat pengaruh antara faktor internal terhadap prestasi belajar mahasiswa. Hal ini mengindikasikan bahwa faktor internal yang sifatnya jasmaniah seperti kesehatan dan cacat tubuh, dan yang sifatnya rohani seperti minat, motivasi, kematangan, perhatian, bakat dan kesiapan, kondisi fisiologi, kondisi psikologis, minat, bakat, motivasi dan perhatian mahasiswa dalam mengikuti perkuliahan dengan baik, maka akan dapat menghasilkan prestasi belajar yang memuaskan meskipun faktor eksternal seperti kondisi gedung, alat/media mengajar dan kurikulum belum sepenuhnya memadai serta kondisi ekonomi 
mahasiswa itu sendiri yang belum cukup stabil. Hasil yang sama juga diperoleh pada penelitian yang dilakukan oleh Sri Rahayu dan Desy Anggareni (2014) bahwa faktor interal berpengaruh secara signifikan terhadap prestasi belajar mahasiswa akuntansi secara parsial dan penelitian yang dilakukan oleh Bendot Tri Utomo (2012) bahwa faktor internal signifikan lebih dominan mempengaruhi hasil belajar mahasiswa pada mata kuliah trigonometri daripada faktor eksternal. Lebih lanjut, hasil penelitian ini juga menunjukkan bahwa faktor eksternal tidak berpengaruh signifikan terhadap prestasi belajar mahasiswa program studi pendidikan matematika ditandai dengan ditolaknya Ho pada hipotesis kedua dalam penelitian ini. Namun secara simultan baik faktor internal maupun faktor eksternal berpengaruh secara signifikan terhadap prestasi belajar mahasiswa. Hasil dari penelitian ini masih perlu dijabarkan dengan meninjau masing-masig sub variabel dari setiap variabel independen sehingga persentase dari distribusi masing-masing sub-sub variabel faktor internal maupun faktor eksternal secara umum dapat dilihat.

\section{Simpulan dan Saran}

\section{Simpulan}

Penelitian ini bertujuan untuk mengidentifkasi faktor-faktor yang berpengaruh signifikan terhadap prestasi belajar. Studi ini dilakukan pada Program Studi Pendidikan Matematika di Universitas Timor. Berdasarkan analisis hasil penelitian yang telah dilakukan dengan menggunakan SPSS dapat ditarik kesimpulan sebagai berikut:

1. Faktor internal berpengaruh signifikan dan positif terhadap prestasi belajar mahasiswa program studi pendidikan matematika. Sedangkan faktor eksternal tidak berpengaruh signifikan terhadap prestasil belajar mahasiswa program studi pendidikan matematika. Dengan kata lain, faktor internal signifikan lebih dominan mempengaruhi prestasi belajar mahasiswa.

2. Faktor internal dan faktor eksternal berpengaruh signifikan secara simultan atau bersama-sama terhadap prestasi belajar mahasiswa program studi pendidikan matematika.

\section{Saran}

Ruang lingkup penelitian ini hanya dilakukan pada program studi pendidikan matematika mata kuliah kalkulus lanjut sehingga hasil penelitian ini terbatas generalisasinya. oleh karena itu, peneliti selanjutnya diharapkan dapat dilakukan pada ruang lingkup yang lebih luas. Selain itu, peneliti yang hendak melaksanakan penelitian yang relevan dengan penelitian ini agar dapat mengkaji lebih jauh menambahkan variabel-variabel lain yang diduga berpengaruh dalam upaya untuk mengatasi rendahnya prestasi belajar mahasiswa dalam mempelajari Kalkulus Lanjut.

\section{Daftar Pustaka}

Ahmadi, A. (2004). Psikologi Pendidikan. Jakarta: Rineka Cipta.

Rahyau, S. dan Anggareni, D. (2014). Faktor-Faktor yang Mempengarhi Prestasi Belajar Mahasiswa

Program Studi Akuntansi. Vol. 3 No.2 Oktober 2014. ISSN: 22527141.

Slameto. (2010). Belajar dan Faktor-Faktor yang Mempengaruhinya. Jakarta: Pustaka Indonesia. . (2003). Belajar dan Faktor-Faktor yang Mempengaruhinya. Jakarta: Rineka Cipta.

Suryabrata, S. (2006). Psikologi Pendidikan. Jakarta: PT Raja Grafindo Persada.

Syah, M. (2010). Psikologi Pendidikan dan Pendekatan Baru. Bandung: PT Remaja Rosdakarya. (2007). Psiklogi belajar. Jakarta: PT Raja Grafindo Persada

Utomo, Bendot T. (2012). Analisis Faktor-Faktor yang Mempengaruhi Rendahnya Hasil Belajar

Trigonometri pada Mahsiswa Prodi pendidikan Matematika STKIP PGRI Lumajang. JP3 Vol 2

No 1, Maret 2012. 